Cornblath, M., Wybregt, S.K., Baens, G.S. \& Klein, R.I. (1964) Symptomatic neonatal hypoglycaemia: studies of carbohydrate metabolism in the newborn infant. VIII. Pediatrics, 33, 388.

Cornblath, M. \& Schwartz, R. (1966) Disorders of Carbohydrate Metabolism in Infancy, p. 82. Saunders, Philadelphia.

Craig, J.M. \& Landing, B.H. (1951) Anaplastic cells of fetal adrenal cortex. American Journal of Clinical Pathology, 21, 940.

Fraumeni, J.F. \& Miller, R.W. (1967) Adrenocortical neoplasms with hemihypertrophy, brain tumors and other disorders. Journal of Pediatrics, 70, 129.

Fraumeni, J.R., Geiser, C.F. \& ManNing, M.D. (1967) Wilms' tumor and congenital hemihypertrophy: report of five new cases and review of literature. Pediatrics, 40, 886.

HARRIS, F. (1969) Exomphalos-Macroglossia Syndrome (Beckwith). Proceedings of the Royal Society of Medicine. (In press.)

HePtinstall, R.H. (1966) Pathology of the Kidney, p. 93. Churchill, London.
IRVING, I.M. (1967) Exomphalos with macroglossia: a study of eleven cases. Journal of Pediatric Surgery, 2, 499.

KerenYI, N. (1961) Congenital adrenal hypoplasia. Report of a case with extreme adrenal hypoplasia and neurohypophyseal aplasia. Archives of Pathology, 71, 336.

Potter, E.L. (1952) Pathology of the Fetus and Newliorn, 1st edn, p. 13. Year Book Publishers, Chicago.

Shafer, A.D. (1968) Primary macroglossia. Clinical Pediatrics, 7, 357.

Sherman, F.E., Bass, L.W. \& Fetterman, G.H. (1958) Congenital rnetastasizing adrenal cortical carcinoma associated with cytomegaly of the fetal adrenal cortex. American Journal of Clinical Pathology, 30, 439.

WiLson, F.C. \& ORLIN, H. (1965) Crossed congenital hemihypertrophy associated with Wilms' tumor. Journal of Bone and Joint Surgery, 47A, 1609.

WiedemanN, H.R. (1964) Complexe malformatif familial avec hernie ombilical et macroglossei, un 'syndrome nouveau'. Journal de Génétique humaine, 13, 223.

\title{
Peripheral sensorimotor neuropathy in association with a seminoma of an undescended testicle
}

\author{
W. A. LitTler \\ M.B., Ch.B., M.R.C.P. \\ Senior House Officer in Medicine, \\ Royal Southern Hospital, Liverpool
}

\section{Introduction}

Denny-Brown (1948) described two cases of sensory neuropathy associated with occult carcinoma of the bronchus. Since then various neurological syndromes, which seem unrelated to neural metastases, have been described; these include cortical cerebellar degenerations, sensory neuropathy, mixed forms, sensorimotor forms and neuromuscular disorders. Brain \& Henson (1958) first used the term 'carcinomatous neuromyopathy' to describe this group. Croft \& Wilkinson (1965) examined 1521 patients admitted to hospital because of some form of carcinomatosis and found evidence of neuromyopathy in over $10 \%$ (162 cases) of the whole series. Bronchial carcinoma is the one most commonly associated with neuromyopathy but other malignant tumours have been incriminated, including ovarian, gastro-intestinal, mammary, oesophageal, prostatic and uterine carcinomas, multiple myeloma and disseminated lymphoma. In a recent review of this subject Croft \& Wilkinson (1969) listed one case of a seminoma associated with a peripheral sensorimotor neuropathy. The following case report is an example of a sensorimotor neuropathy associated with a seminoma of an undescended testicle.

\section{Case report}

The patient, a 53-year-old bachelor was admitted to hospital with a 3 week history of progressive numbness and weakness in both his hands and feet. He smoked thirty-five cigarettes a day and drank up to 6 pints of beer every night, but ate regular, adequate meals cooked for him by his sister. He worked as a dock labourer. He had not been treated with any neurotoxic drugs and there was no family history of neurological disease. Twenty years earlier a left sided inguinal hernia had been repaired; the hernia had been associated with an undescended testicle and the patient had been told that the left testicle was within the abdomen and had not been removed (no clinical notes available).

Examination showed a thin, ill-looking man. The cardiovascular and respiratory systems were clinically normal. Palpation of the abdomen revealed a fixed, non-tender, cystic mass, the size of a grapefruit, in the left iliac fossa. The spleen was thought to be enlarged 3 in below the left costal margin. The left testicle was absent from the scrotum, the right testicle appeared normal. Rectal examination was normal. In the central nervous system there were signs of a sensorimotor neuropathy with loss of sensation to all modalities in the glove-and-stocking 
distribution, associated with weakness of all four limbs most marked distally; there was slight wasting of the small muscles of the hands. Both ankle jerks were absent, the knee and the upper limb reflexes were depressed. The plantar responses were equivocal and the gait was ataxic.

Investigations. Haemoglobin $12 \cdot 8 \mathrm{~g} / 100 \mathrm{ml}$; WBC $6000 / \mathrm{mm}^{3}$ with a normal differential; ESR $30 \mathrm{~mm} /$ $\mathrm{hr}$; blood urea $20 \mathrm{mg} / 100 \mathrm{ml}$; serum sodium 134, potassium 4.5 and chloride $95 \mathrm{mEq} / 1$; serum $B_{12} 260$ $\mathrm{Pg} / 100 \mathrm{ml}$; serum folate $5.2 \mathrm{ng} / 100 \mathrm{ml}$; plasma proteins: albumin $3.9 \mathrm{~g} / 100 \mathrm{ml}$, globulin $2.4 \mathrm{~g} / 100 \mathrm{ml}$ $\left(\alpha_{1} 0 \cdot 1, \alpha_{2} 0 \cdot 7, \beta 0.5, \gamma 1 \cdot 1 \mathrm{~g} / 100 \mathrm{ml}\right)$; alkaline phosphatase $11 \mathrm{KA}$ units; acid phosphatase $3 \mathrm{KA}$ units; latex fixation test for RA factor negative; no LE cells seen; Paul-Bunnell test negative; liver function, glucose tolerance and pyruvate tolerance tests all normal; urine analysis was normal; cerebrospinal fluid: protein $40 \mathrm{mg} / 100 \mathrm{ml}$, sugar $70 \mathrm{mg} / 100 \mathrm{ml}$, chlorides $751 \mathrm{mg} / 100 \mathrm{ml}, 10 \mathrm{WBC} / \mathrm{mm}^{2}$; WR negative in CSF and blood. Radiographs of the chest, skull and cervical spine were normal; a radiograph of the abdomen showed a soft tissue shadow in the left mid-abdomen and the spleen appeared enlarged; a percutaneous liver biopsy showed normal hepatic tissue; scalene node biopsy was normal.

Operation. A laparotomy was carried out, and a huge, necrotic retroperitoneal tumour was found. This tumour was in two discrete masses, the lower one involving the mesosigmoid and the upper involving the mesentery of the jejunum; the latter was, in fact, the mass, which was thought clinically to be an enlarged spleen. The spleen was normal in size. The tumour was considered to be inoperable. A biopsy taken at operation showed that the tumour was a seminoma of the testis, with many mitoses and large areas of necrosis.

The patient was given a course of local radiotherapy to the abdominal tumour. As a result, the mass was reduced to a third of its original size and, there was in addition, a marked improvement in the peripheral neuropathy with an almost complete return of sensation and power in the patient's hands and feet. The patient is alive 4 months afterwards with no further deterioration in his neurological signs.

\section{Discussion}

Croft \& Wilkinson (1965) commented 'as more examples of neuromyopathy are seen, it becomes apparent that any type of neuromyopathy may occur with any type of malignant disease'. This patient had clinical signs consistent with a peripheral sensorimotor neuropathy and with a history of an undescended, intra-abdominal testicle and the subsequent development of an abdominal mass, malignant change in that testicle was considered likely. The risk of cancer for a man who has a maldescended testicle is said to be fifty times greater than the risk to a man with both testicles fully descended (Campbell, 1959). Twelve and a half per cent of tumours associated with maldescent arise in abdominal testes (Ferguson, 1965). The suspicion of this being a malignant tumour was confirmed by biopsy. Other causes of a peripheral neuropathy such as bronchial carcinoma, diabetes mellitus, vitamin deficiency, drugs and collagen disorders were excluded by investigation. The remarkable improvement of this neuropathy after the tumour had been treated with radiotherapy may just possibly have been coincidental, though it is difficult to discount the effects of the radiotherapy. Brain \& Henson (1958) mentioned the striking spontaneous remissions that occur with some cases of the mixed forms of neuromyopathy while Croft, Urich \& Wilkinson (1967), dividing patients with carcinomatous sensorimotor neuropathy into three groups based on the clinical course of the disorder found their third group to show a strong tendency to spontaneous remission and sometimes relapse. It is interesting that the case of seminoma associated with a sensorimotor neuropathy listed by Croft \& Wilkinson (1969) fell into this remitting and relapsing group.

\section{Acknowledgments}

I would like to thank Dr R. W. Brookfield for permission to publish this case and Mrs Bode for typing the script.

\section{References}

Brain, W.R. \& Henson, R.A. (1958) Neurological Syndromes associated with carcinoma: the carcinomatous neuromyopathies. Lancet, ii, 971.

Campbell, H.E. (1959) The incidence of malignant growth of the undescended testicle: a reply and re-evaluation. Journal of Urology, 81, 663.

Croft, P.B. \& Wilkinson, M. (1965) The incidence of carcinomatous neuromyopathy in patients with various types of carcinoma. Brain, 88, 427.

Croft, P.B. \& Wilkinson, M. (1969) The course and prognosis in some types of carcinomatous neuromyopathy. Brain, 92, 1.

Croft, P.B., Urich, H. \& Wilkinson, M. (1967) Peripheral neuropathy of sensorimotor type associated with malignant disease. Brain, 90, 31.

Denny-Brown, D. (1948) Primary sensory neuropathy with muscular changes associated with carcinoma. Journal of Neurology, Neurosurgery and Psychiatry, 11, 73.

Ferguson, J.D. (1965) XIIIe Congrès de la Société Internationale d'Urologie, p. 72. Livingstone, Edinburgh. 